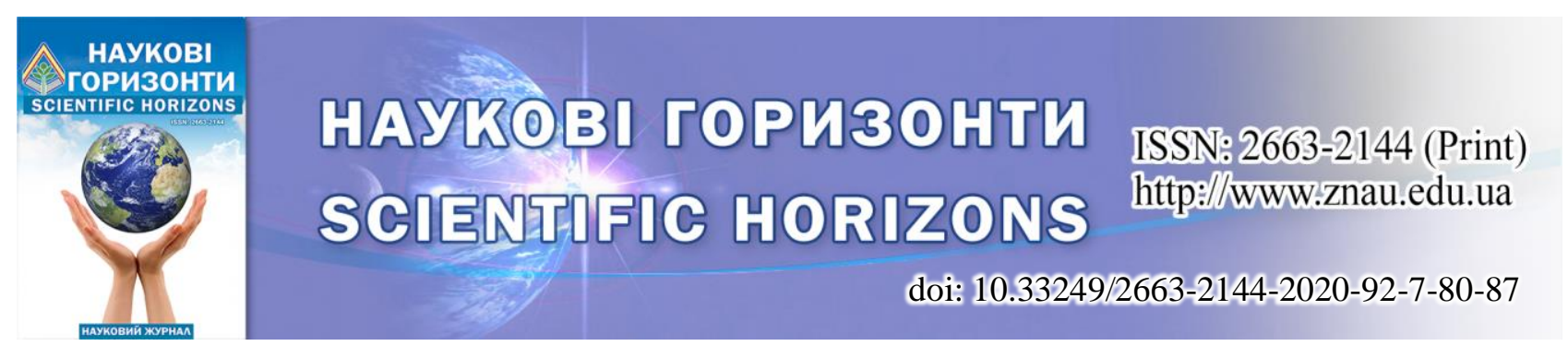

UDC 575.17.575.21:577.21

\title{
CHANGING THE RATIO OF FEED IN THE DIET - A TECHNOLOGICAL WAY TO INCREASE SCAR FERMENTATION AND PRODUCTIVITY OF ANIMALS
}

Article info
Received
04.05.2020
Accepted
24.06 .2020
1 Sumy National
Agrarian
University
160,
G. Kondratieva
Str.,
Sumy,
40000, Ukraine
2 Poltava State
Agrarian
Academy
1/3,

Scovorody Str., Poltava, 36003, Ukraine

E-mail:

kaf.anatomia@ ukr.net; ganavar@ukr.net

\section{Kambur ${ }^{1}$, A. Zamazij ${ }^{2}$}

Kambur, M., Zamazij, A. (2020). Changing the ratio of feed in the diet a technological way to increase scar fermentation and productivity of animals. Scientific Horizons, 07 (92), 80-87. doi: 10.33249/2663-2144-2020-92-7-80-87.

An important technological technique in production in order to increase the level of assimilation of feed by animals and increase their productivity is the ratio of different types of feed in the diet. Under these conditions, animals change the course of metabolic processes in the rumen and cause changes in metabolism, activate or inhibit the adsorption of precursors by breast tissue of cows for the synthesis of milk components.

To this end, we studied the processes of cicatricial fermentation of the conditions of change in the ratio in the diet of green fodder, grass pellets and grain concentrates. This technique allows to intensify the processes of scar fermentation, increase the adsorption capacity of breast tissue of animals, accompanied by increased synthesis of volatile fatty acids, in which the proportion of acetic acid in animals of the second and third groups increases during the experiment by an average of 1.1-21.17 times $(p<0.05)$. The increase in the content of LH in the scar of animals of the second and third groups was possible due to the increase in the content of the scar of amylolytic microorganisms on average during the experiment by 1.25 times $(p<0.05)$, proteolytic 1.24 times $(p<0,05)$, and cellulolytic 1.27 times in animals of the second group and 1.68 times in cows of the third group $(p<0.01)$.

All this affected the amino acid composition of the scar content of animals of the second group in which the content of essential amino acids was $8.24 \%$, and in animals of the third group by $12.86 \%$ more than in cows of the first group. The total amino acid pool of the contained scar was probably larger in the cows of the experimental groups, because the replacement of amino acids in it was found by 10.0-10.8\% more than in the animals of the first group. The level of breast tissue of cows with precursors for the synthesis of milk components due to changes in the ratio of different groups of feeds in the diet increased their absorption capacity during intensive lactation, which indicates a positive effect on the productivity of cows.

Key words: volatile fatty acids, adsorption, composition, milk.

\section{ЗМІНА СПІВВІДНОШЕННЯ КОРМІВ В РАЦІОНІ - ТЕХНОЛОГІЧНИЙ ПРИЙОМ ПІДВИЩЕННЯ РУБЦЕВОЇ ФЕРМЕНТАЦІЇ ТА ПРОДУКТИВНОСТІ КОРІВ}

\author{
М. Д. Камбур ${ }^{1}$, А. А. Замазій ${ }^{2}$ \\ ${ }^{1}$ Сумський національний аграрний університет \\ вул. Г. Кондратьева, 160, м. Суми, 40000, Україна \\ ${ }^{2}$ Полтавська державна аграрна академія \\ вул. Сковороди, 1/3, м. Полтава, 36003, Україна
}

Важливим технологічним прийомом у виробництві, з метою підвищення рівня засвоєння корму тваринами та підвищення їх продуктивності, є співвідношення різних видів корму в раціоні. За ц̧их 
умов у тварин змінюється перебіг метаболічних процесів у рубці та викликає змини у обміні речовин, активує або гальмує адсорбиію попередників тканинами молочної залози корів для синтезу складових компонентів молока. 3 иією метою ми досліджували процеси рубиевої ферментаиії умов зміни співвідношення в рачіоні зелених кормів, трав'яних гранул та зернових концентратів. Такий прийом дозволив активізувати прочеси рубиевої ферментації, підвищити адсорбиійну здатність тканин молочної залози тварин, щзо супроводжується підвищенням синтезу летких жирних кислот, в яких частка оцтової кислоти, у тварин другої та третьої груп підвищується за період досліду в середньому 1,12-1,17 раза (p<0,05). Підвищення вмісту ЛЖК у рубиі тварин другої та третьої груп стало можливим за рахунок підвищення у вмістимому рубия кількості амілолітичних мікроорганізмів y середньому за період досліду в 1,25 раза $(p<0,05)$, протеолітичних у 1,24 раза $(p<0,05)$, a иелюлозолитичних у 1,27 раза у тварин другої групи та в 1,68 раза у корів третьої групи ( $p<0,01)$. Все ие вплинуло на амінокислотний склад вмістимого рубия тварин другої групи, в якому вміст незамінних амінокислот виявився на 8,24 \%, а у тварин третьої групи на 12,86 \% більще, ніж у корів першої групи. Загальний амінокислотний пул вмістимого рубия був у корів дослідних груп вірогідно більше, оскільки i замінних амінокислот в ньому виявлено на 10,0-10,8 \% більше, ніж у тварин першої групи. На фоні проведених досліджень встановлено активачію поглинальної здатності тканин молочної залози корів у період інтенсивної лактації, що свідчить про позитивний вплив даного прийому на продуктивність корів.

Ключові слова: леткі жирні кислоти, адсорбиї̈, склад, молоко.

\section{Вступ}

Важливість виявлення глибинних механізмів рубцевої ферментації та молоко синтезуючої функції молочної залози в усі періоди ії діяльності полягає в тому, що саме рівень рубцевої ферментації $\epsilon$ провідним у характері молокоутворюючої функції молочної залози. Аналіз кормової бази, рівня і типу годівлі вказує, що одним 3 головних факторів, який негативно впливає на використання корму, його конверсію у продукцію, $є$ порушення співвідношення рівня надходження поживних речовин в організм тварин і можливість їх інтенсивного використання тканинами молочної залози для синтезу компонентів молока у різні фізіологічні періоди їх життєдіяльності (Zamazij et al., 2017), втрачені результати багаторічних досліджень в галузі селекції великої рогатої худоби та стада високопродуктивних корів. Значно знизилося поголів'я молочної худоби, що потребує значного перегляду питання щодо селекції, відтворення і годівлі корів (Yablonski, 2000). I в цій площині важливого значення набуває активація процесів рубцевої ферментації 3 метою інтенсифікації синтезу оцтової, масляної, пропіонової кислот та мікробіальної i протозойної маси, які використовуються організмом тварин для секретоутворення у молочній залозі, а відповідно, і отримання максимальної продукції від кожної корови (Russel \& Rychlik, 2001; Kambur et al., 2018).

Дослідження обмінних процесів, які протікають в організмі продуктивних тварин, повинно забезпечити можливість визначення потреб організму в субстратах, необхідних для біосинтезу компонентів молока i отримання якісної продукції (Chung et al., 2012). Потреба тварин в енергії i поживних речовинах забезпечується в кінцевому результаті набором метаболітів не тільки тих, що надходять 3 кормом, але й тих, що утворюються в процесі травлення та вторинного метаболізму в тканинах. Все це робить суттєвим вивчення питань 3 використання молочною залозою метаболітів рубцевої ферментації (Bauman \& Griinari, 2002; Schlegel et al., 2012).

Забезпечення тварин кормами, зміна їх співвідношення та надходження в організм необхідних поживних речовин $\epsilon$ важливим технологічним прийомом у виробництві з метою підвищення рівня засвоєння корму коровами та їх продуктивності. Співвідношення різних видів корму в раціоні тварин змінюе течію метаболічних процесів у рубці, викликає змини у обміні речовин, активує або гальмує адсорбцію попередників тканинами молочної залози корів для синтезу складових компонентів молока. Доведено, що (Hajrullin et al., 2020) зміна забезпеченості корів енергією, протеїном, легкоперетравними вуглеводами є складовими у процесах живлення тварин, впливає на активність тканин молочної залози щодо адсорбції попередників 3 притікаючої крові. Для метаболічних процесів, які відбуваються у 
тканинах молочної залози і $\dddot{11}$ секреторних клітинах, характерна дуже висока активність, тому що окрім обов'язкових структурних компонентів для кожної клітини вони синтезують ще і основні компоненти молока - білок, жир, лактозу (Bauman et al., 2008). Вміст компонентів у молоці непостійний протягом лактації і навіть упродовж доби у однієї і тієї ж тварини. На наш погляд, ця варіаційність обумовлена цілою низкою зовнішніх та внутрішніх факторів, вивчення яких вкрай необхідне 3 метою регулювання вмісту цих компонентів у молоці. Потреба у амінокислотах повинна визначатися 3 врахуванням спожитого корму (обмінної енергіi), розподілом енергії між тканинами організму i молоком, складу молока і періоду лактації. Період лактації необхідно враховувати, так як лактація циклічний процес, у якому показники продуктивності можуть суттєво впливати на наступну молокопродукцію. Доведено, що глюкоза також може використовуватися для синтезу амінокислот казеїну молока. Складною і суперечливою досі залишається думка дослідників з питання синтезу жиру молока (Medinger et al., 2010). Окрім кількості та якості корму на склад жиру та жирних кислот у крові впливає також надходження різноманітних добавок. Встановлено корелятивний зв'язок між рубцевими метаболітами і синтезом молочного жиру у жуйних тварин. Важливою особливістю процесів травлення у жуйних тварин $є$ те, що корм підлягає в рубці впливу мікроорганізмів та простіших (Pappritz et al., 2011; Newbold et al., 2015; Sachuk et al., 2018). За цих умов відбувається зброджування целюлози, крохмалю, пентозу, вуглеводів. Мікрофлора рубця передшлунків жуйних тварин знаходиться у симбіотичних відносинах 3 організмом тварин, та складає з ним єдине ціле. По-перше, мікроорганізми забезпечують макроорганізм енергетичним матеріалом, ферментуючи вуглеводні компоненти корма до ЛЖК, з іншого боку, у процесі життєдіяльності мікроорганізми накопичують у власних клітинах легкотравний білок, глікоген подібні полісахариди, які в кінцевому результаті використовуються для живлення організму тварини - хазяїна.

\section{Матеріали і методи дослідження}

Метою роботи було - дослідити синтез метаболітів рубцевої ферментації та продуктивність корів за умов зміни співвідношення кормів у раціоні.

Експериментальну частину роботи виконували в умовах ПП «ЯНА ПЛЮС» Чернігівської області, с. Петрівка, віварію факультету ветеринарної медицини, кафедри анатомії, нормальної та патологічної фізіології СНАУ. Дослідження проводили протягом 20182019 рр. у весняно-літній період на коровах чорно-рябої породи, в раціонах яких змінювали співвідношення кормів по енергетичній поживності як технологічний прийом підвищення активності рубцевої ферментації та продуктивності тварин (табл. 1).

Таблиия 1. Співвідношення кормів за енергетичною поживністю, \%

\begin{tabular}{|c|c|c|c|}
\hline \multirow{2}{*}{ Групи тварин } & \multicolumn{3}{|c|}{ Види кормів } \\
\cline { 2 - 4 } & зелені корма & трав'яні гранули & зернові концентрати \\
\hline I & $60(6,10$ к.од.) & $30(3,05$ к.од.) & $10(1,01$ к.од.) \\
\hline II & $60(6,10$ к.од.) & $20(2,03$ к.од.) & $20(2,02$ к.од.) \\
\hline III & $60(6,10$ к.од.) & $10(1,20$ к.од.) & $30(3,03$ к.од.) \\
\hline
\end{tabular}

Дослідження впливу різного співвідношення груп кормів раціону на процеси рубцевої ферментації та продуктивність корів проводили впродовж перших трьох місяців лактації. Для досліду було сформовано 3 групи тварин, по 10 корів у кожній. Тваринам першої групи впродовж досліду (контроль) у раціоні забезпечували $60 \%$ зелених кормів, 30 \% трав'яних гранул та $10 \%$ зернових концентратів. Тваринам другої групи призначали $60 \%$ зелених кормів, $20 \%$ трав'яних гранул та $20 \%$ зернових концентратів. Корови третьої групи за період досліду отримували з раціоном 60 \% зелених кормів, $10 \%$ трав'яних гранул та $30 \%$ зернових концентратів.

Відбір проб крові від тварин дослідних груп проводили в кінці кожного місяця досліду 3 хвостової артерії, а вміст рубця отримували за допомого зонду з використанням колби Бунзена, $(\mathrm{n}=5)$.

У зразках вмістимого рубця визначали концентрацію ЛЖК методом відгонки у апараті Маркгама, оцтової кислоти - мікродифузним методом у чашках Конвея, В-оксимасляної кислоти - за Єнгфельдом у модифікації 
С. М. Лейтеса та А. І. Одинової, глюкози методом Хіварінена-Ніккіла, загального білка рефрактометричним та біуретовим методом (Vlizlo et al., 2004).

Кількість амілолітичних, целюлозолітичних та протеолітичних мікроорганізмів визначали шляхом висіву розведеного до $10^{6}$ вмісту рубця на елективне середовище за Р. Y. Provos, R. N. Dotsch, по R. F. Hungate, та за R. S. Fulganum W. E. Moore (Chumachenko et al., 1989). Інкубування амілолітичних та протеолітичних мікроорганізмів проводили впродовж трьох діб, целюлозолітичних - впродовж трьох тижнів в анаеростатах Аристовського у термостаті, за температури $37-39^{\circ} \mathrm{C}$. Колонії мікроорганізмів підраховували за допомогою спеціального лічильника бактерій.

Амінокислотний склад маси мікроорганізмів визначали на амінокислотному аналізаторі AAA339.

Визначення вмісту основних класів ліпідів у зразках молока проводили методом атомнодесорбційної мас-спектрометрії (PDMS) на масспектрометрі виробництва «МСБХ» в умовах відділу № 20 Інституту прикладної фізики НАН України (м. Суми). Задля визначення вмісту ліпідів використовували значення молекулярної маси (M/z) та інтенсивності піків квазимолекулярних іонів (КМI), які відповідають зазначеним речовинам. Інтенсивність КМІ виражали в каунтах.

Результати досліджень оброблені статистично за допомогою комп'ютерної програми. Визначали середню арифметичну (M), статистичну помилку середньої арифметичної (m), вірогідність різниці (p) між середніми даними за критерієм вірогідності (t) Стьюдента. Різницю між двома величинами вважали вірогідною за $\mathrm{p}<0,05 ; \mathrm{p}<0,01 ; \mathrm{p}<0,001$.

Під час проведення експериментальних досліджень дотримуватися міжнародних вимог щодо захисту тварин від жорстокого поводження.

\section{Результати досліджень та обгрунтування}

В результаті проведених досліджень нами встановлено, що зміна співвідношення кормів у раціоні корів впливає на рубцеву ферментацію. Зміна співвідношення в раціоні тварин зернових концентратів по поживності з $10 \%$ до $30 \%$, а трав'яних гранул $3 \quad 30 \%$ до $10 \%$ сприяло активації синтезу летких жирних кислот в рубці. Водночас підвищується кількість мікроорганізмів у вмістимому рубця і їх специфічна активність, що співпадає 3 даними дослідників, які вказують на активацію процесів рубцевої ферментації, за умов використання різноманітних добавок в годівлі тварин. Про активацію течії процесів рубцевої ферментації свідчить вміст ЛЖК у рубці (табл. 2).

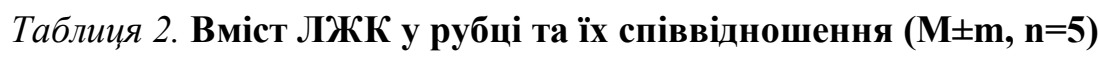

\begin{tabular}{|c|c|c|c|c|}
\hline \multirow{2}{*}{ Показники } & \multirow{2}{*}{ Період досліду } & \multicolumn{3}{|c|}{ Групи тварин } \\
\hline & & I & II & III \\
\hline \multirow{4}{*}{$\begin{array}{l}\text { Концентрація ЛЖК у } \\
\text { рубці, (Ммоль/100 мл) }\end{array}$} & Початок досліду & $7,54 \pm 0,52$ & $7,56 \pm 0,48$ & $7,52 \pm 0,36$ \\
\hline & I місяць & $7,92 \pm 0,26$ & $7,98 \pm 0,52$ & $8,24 \pm 0,42$ \\
\hline & II місяць & $7,96 \pm 0,32$ & $8,36 \pm 0,44$ & $8,78 \pm 0,48^{*}$ \\
\hline & III місяць & $7,86 \pm 0,34$ & $8,94 \pm 0,36$ & $9,26 \pm 0,18$ \\
\hline \multicolumn{5}{|l|}{ у т.ч. в М \%: } \\
\hline \multirow{4}{*}{ Оцтова кислота } & Початок досліду & 63,96 & 64,02 & 63,92 \\
\hline & I місяць & 60,84 & 65,14 & 66,36 \\
\hline & II місяць & 61,26 & 66,48 & $68,54 *$ \\
\hline & III місяць & 61,08 & 67,92 & $69,86^{*}$ \\
\hline \multirow{4}{*}{ Пропіонова кислота } & Початок досліду & 15,64 & 15,72 & 15,56 \\
\hline & І місяць & 15,86 & 16,46 & 16,94 \\
\hline & II місяць & 16,02 & 17,52 & $18,36^{*}$ \\
\hline & III місяць & 15,94 & 17,98 & $19,24 *$ \\
\hline \multirow{4}{*}{ Масляна кислота } & Початок досліду & 15,26 & 15,34 & 15,42 \\
\hline & І місяць & 15,32 & 15,56 & 15,84 \\
\hline & II місяць & 15,94 & 16,26 & 16,72 \\
\hline & III місяць & 15,66 & 16,34 & 16,98 \\
\hline
\end{tabular}

Примітка: $\mathrm{p}<0,05 ; \mathrm{p}<0,01 ; \mathrm{p}<0,001$ у порівнянні з контрольною групою. 
Необхідно вказати, що підвищення енергетичної забезпеченості раціону за рахунок зернових концентратів до $30 \%$ і зниження трав'яних гранул до $10 \%$ суттєво вплинуло на співвідношення летких жирних кислот, вміст яких коливався від 7,54 $\pm 0,52$ до 7,96 $\pm 0,32$ Ммоль/100 мм. Із загальної кількості ЛЖК у вмісті рубця, частка оцтової кислоти, у тварин першої групи практично не змінилася впродовж досліду і становила від 63,96 до 60,84 М \%. В той же час, у тварин другої групи загальна кількість ЛЖК у рубці послідовно підвищувалася впродовж досліду в 1,06 , в 1,11 та в 1,18 раза у порівнянні з їх вмістом у рубці тварин на початку досліду. Дана картина більш виразною була у тварин третьої групи. На початку досліду загальний вміст ЛЖК у рубці тварин третьої

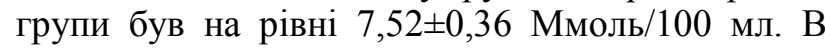
послідуючому, впродовж трьох місяців досліду, ïх вміст підвищувався в $1,10(\mathrm{p}<0,05)$, в 1,17 та в 1,23 раза $(\mathrm{p}<0,01)$. Кількість оцтової кислоти у вмісті рубця тварин другої групи виявився впродовж досліду в 1,07 , в 1,09 та в 1,11 раза більше, ніж у корів першої групи $(\mathrm{p}<0,05)$. Значно більше виявився вміст оцтової кислоти у рубці корів третьої групи. У порівнянні 3 тваринами першої групи даний показник був у період досліду в 1,09 , в 1,12 та 1,14 раза більше у вмісті рубця корів третьої групи. Водночас необхідно відмітити i тенденцію підвищення кількості масляної кислоти у вмісті рубця корів другої та третьої груп. Однак, у крові тварин цих двох груп нами не встановлено вірогідного підвищення вмісту кетонових тіл у крові. Підвищення вмісту ЛЖК у рубці тварин дослідних груп (другої та третьої груп) стало можливим за рахунок підвищення кількості мікроорганізмів. Кількість амілолітичних мікроорганізмів у рубці корів першої групи коливалася від $3,86 \pm 0,24$ до $3,94 \pm 0,26$ млн/мл. У тварин другої групи (табл. 3) підвищилася до кінця першого місяця досліду в $1,12$ раза , другого - в 1,18 раза ( $<<0,01)$, а третьої в 1,22 раза $(\mathrm{p}<0,01)$.

Таблиця 3. Кількісний склад та ферментативна активність мікроорганізмів рубця $(\mathbf{M} \pm \mathbf{m}, \mathbf{n}=\mathbf{5})$

\begin{tabular}{|c|c|c|c|c|}
\hline \multirow{2}{*}{ Показники } & \multirow{2}{*}{ Період досліду } & \multicolumn{3}{|c|}{ Групи тварин } \\
\hline & & I & II & III \\
\hline \multicolumn{5}{|c|}{ Кількість мікроорганізмів, млн/мл: } \\
\hline \multirow[t]{4}{*}{ - амілолітичних } & Початок досліду & $3,86 \pm 0,24$ & $3,82 \pm 0,22$ & $3,78 \pm 0,36$ \\
\hline & І місяць & $3,92 \pm 0,32$ & $3,98 \pm 0,42$ & $4,42 \pm 0,44 *$ \\
\hline & II місяць & $3,78 \pm 0,28$ & $4,36 \pm 0,38$ & $4,96 \pm 0,38 *$ \\
\hline & III місяць & $3,94 \pm 0,26$ & $4,54 \pm 0,28$ & $5,02 \pm 0,34 *$ \\
\hline \multirow[t]{4}{*}{ - протеолітичних } & Початок досліду & $10,24 \pm 0,86$ & $10,14 \pm 0,72$ & $10,08 \pm 0,42$ \\
\hline & I місяць & $9,96 \pm 0,72$ & $11,36 \pm 0,86$ & $11,88 \pm 0,56$ \\
\hline & II місяць & $10,12 \pm 0,64$ & $11,88 \pm 0,54$ & $12,44 \pm 0,66^{*}$ \\
\hline & III місяць & $10,08 \pm 0,82$ & $12,32 \pm 0,46$ & $13,02 \pm 0,38^{*}$ \\
\hline \multirow[t]{4}{*}{ - целюлозолітичних } & Початок досліду & $2,56 \pm 0,12$ & $2,52 \pm 0,14$ & $3,02 \pm 0,16$ \\
\hline & І місяць & $2,68 \pm 0,16$ & $3,02 \pm 0,22$ & $3,94 \pm 0,22 *$ \\
\hline & II місяць & $2,54 \pm 0,24$ & $3,36 \pm 0,28^{*}$ & $4,42 \pm 0,18 * *$ \\
\hline & III місяць & $2,72 \pm 0,18$ & $3,72 \pm 0,32 *$ & $4,96 \pm 0,32 * *$ \\
\hline \multicolumn{5}{|c|}{ Спеціфічна активність мікроорганізмів } \\
\hline \multirow{4}{*}{$\begin{array}{l}\text { Амілолітична } \\
\text { активність, } \\
\text { ум. ам. од. }\end{array}$} & Початок досліду & $0,56 \pm 0,08$ & $0,54 \pm 0,06$ & $0,56 \pm 0,08$ \\
\hline & І місяць & $0,58 \pm 0,08$ & $0,64 \pm 0,12^{*}$ & $0,72 \pm 0,08 *$ \\
\hline & II місяць & $0,52 \pm 0,12$ & $0,72 \pm 0,12 *$ & $0,86 \pm 0,12 *$ \\
\hline & III місяць & $0,50 \pm 0,10$ & $0,78 \pm 0,08^{*}$ & $0,92 \pm 0,14 * *$ \\
\hline \multirow{4}{*}{$\begin{array}{l}\text { Протеолітична } \\
\text { активність, пр. од. }\end{array}$} & Початок досліду & $2,36 \pm 0,12$ & $2,42 \pm 0,14$ & $2,38 \pm 0,16$ \\
\hline & I місяць & $2,44 \pm 0,22$ & $2,78 \pm 0,18$ & $2,94 \pm 0,24$ \\
\hline & II місяць & $2,32 \pm 0,18$ & $3,12 \pm 0,22 *$ & $3,56 \pm 0,32 * *$ \\
\hline & III місяць & $2,52 \pm 0,24$ & $3,46 \pm 0,22 *$ & $4,24 \pm 0,28 * *$ \\
\hline \multirow{4}{*}{$\begin{array}{l}\text { Целюлозолітична } \\
\text { активність, \% }\end{array}$} & Початок досліду & $12,36 \pm 0,42$ & $12,18 \pm 0,54$ & $12,20 \pm 0,36$ \\
\hline & І місяць & $12,48 \pm 0,36$ & $13,02 \pm 0,48$ & $13,86 \pm 0,42$ \\
\hline & II місяць & $12,24 \pm 0,54$ & $13,64 \pm 0,62$ & $14,02 \pm 0,48 *$ \\
\hline & III місяць & $11,94 \pm 0,38$ & $13,96 \pm 0,36$ & $14,58 \pm 0,24 *$ \\
\hline
\end{tabular}

Примітка: за $\mathrm{p}<0,05 ; \mathrm{p}<0,01 ; \mathrm{p}<0,001$ у порівнянні $з$ контрольною групою. 
У тварин третьої групи підвищене забезпечення рівнем зернових концентратів сприяло росту кількості амілолітичних мікроорганізмів впродовж досліду в рубці в 1,12 , в 1,31 та в 1,33 раза $(\mathrm{p}<0,01)$. Підвищення кількості протеолітичних мікроорганізмів найбільш значною виявилась у тварин третьої групи: в 1,18 , в 1,23 та в 1,30 раза $(\mathrm{p}<0,01)$ у порівнянні з даним показником на початку досліду. Значним $є$ той факт, що у тварин дослідних груп у рубці значно підвищується кількість та активність целюлозолітичних мікроорганізмів. У корів другої групи у вмістимому рубця кількість целюлозолітичних мікроорганізмів підвищується впродовж досліду в 1,13 , в 1,32 та в 1,37 раза, а у корів третьої групи в 1,47 , в 1,74 та в 1,82 раза у порівнянні з даним показником тварин першої групи $\quad(\mathrm{p}<0,01) . \quad$ Підвищення $\quad$ кількості мікроорганізмів у вмісті рубця тварин дослідних груп вплинув на вміст їх загальної маси (табл. 3). Подібний ефект спостерігали дослідники, за умов введення в раціон ферментативних препаратів та змини співвідношення кормів у раціоні. За нашими даними, у корів першої групи загальна маса мікроорганізмів становила $0,1120 \pm 0,01$ г/100 мл на початку досліду і не вірогідно змінювалася впродовж дослідного періоду. У тварин другої групи загальна маса мікроорганізмів рубця вірогідно підвищилася в кінці другого місяця досліду в 1,11 раза $(\mathrm{p}<0,05)$ та в 1,16 раза $(\mathrm{p}<0,05)$ в кінці третього місяця. У корів третьої групи маса мікроорганізмів у рубці до кінця першого місяця досліду підвищилась в 1,10 раза, в 1,18 та 1,22 раза $(\mathrm{p}<0,05)$. Співвідношення різних кормів у раціоні корів вплинуло на амінокислотний склад вмістимого рубця (табл. 4).

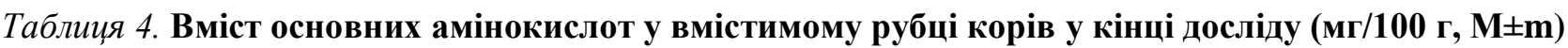

\begin{tabular}{|l|c|c|c|}
\hline \multirow{2}{*}{ Амінокислоти } & \multicolumn{3}{c|}{ Групи тварин } \\
\cline { 2 - 4 } & I & II & III \\
\hline Метіонін & $4,96 \pm 0,52$ & $5,78 \pm 0,48$ & $6,86 \pm 0,36$ \\
\hline Гістидин & $6,92 \pm 0,48$ & $8,26 \pm 0,36$ & $8,72 \pm 0,52$ \\
\hline Лейцин & $19,82 \pm 0,42$ & $19,56 \pm 0,52$ & $19,56 \pm 0,48$ \\
\hline Лізин & $19,54 \pm 0,26$ & $21,88 \pm 0,32$ & $22,44 \pm 0,54$ \\
\hline Всього незамінних кислот & $108,24 \pm 1,32$ & $119,24 \pm 1,46 *$ & $122,06 \pm 2,02 *$ \\
\hline Серин & $12,90 \pm 0,92$ & $3,40 \pm 0,96$ & $14,20 \pm 1,04$ \\
\hline Аспаргінова кислота & $22,40 \pm 1,04$ & $23,56 \pm 1,52$ & $24,42 \pm 1,38$ \\
\hline Тирозин & $11,90 \pm 0,80$ & $13,86 \pm 1,28$ & $14,48 \pm 1,56$ \\
\hline Всього замінних амінокислот & $133,42 \pm 2,42$ & $147,66 \pm 1,96$ & $152,24 \pm 2,02 *$ \\
\hline
\end{tabular}

Примітка: за $\mathrm{p}<0,05 ; \mathrm{p}<0,01 ; \mathrm{p}<0,001$ у порівнянні 3 контрольною групою.

Результати досліджень свідчать про підвищення вмісту амінокислот у мікробіальній масі рубця тварин дослідних груп. У корів першої групи у вмісті рубця всього незамінних амінокислот виявлено на рівні $108,24 \pm 1,32$ мг/100 мл. У корів другої групи вміст незамінних амінокислот виявився на $8,24 \%$, а у тварин третьої групи на $12,86 \%$ більше, ніж у корів першої групи. Загальний амінокислотний пул вмісту рубця був у корів дослідних груп вірогідно більше, оскільки і замінних амінокислот в ньому виявлено на 10,0-10,8 \% більше, ніж у тварин першої групи.

В період досліду поглинальна здатність тканин молочної залози корів другої та третьої груп переважала адсорбційну здатність тканин молочної залози тварин першої групи (табл. 5).
Використання сумарної фракції триацилгліцеролів по молочній залозі корів першої групи у період першого та другого місяців досліджень коливалося від 6,0 до 18,45 \%, що було в 2,161,35 раза та в 2,31-1,24 раза менше, ніж у тварин другої та третьої груп ( $<<0,01)$.

Така динаміка використання сумарної фракції триацилгліцеролів тканинами молочної залози в період досліду вплинула на вміст основних класів ліпідів у молоці корів (табл. 6). Встановлено, що в молоці корів другої та третьої груп вміст фосфорилхоліну був на 2,15-3,08 \%, холестеролу - на 7,72-11,34\% $(\mathrm{p}<0,05)$, сумарної фракції фосфоліпідів - на 12,07-12,38 \% ( $<<0,05)$, а сумарної фракції триацилгліцеролів - на 11,30 $24,37 \% \quad(p<0,01)$ більше, ніж у молоці корів контрольної групи. 
Таблиця 5. Використання сумарної фракції триацилгліцеролів по молочній залозі корів у період досліджень $(\mathrm{M} \pm \mathbf{m}, \mathbf{n}=5$, каунти, \%)

\begin{tabular}{|c|c|c|c|c|}
\hline \multirow{2}{*}{$\begin{array}{c}\text { Групи } \\
\text { тварин }\end{array}$} & \multirow{2}{*}{ Артеріальна кров } & \multirow{2}{*}{ Венозна кров } & \multicolumn{2}{|c|}{ Артеріовенозна різниця (АВ) } \\
\cline { 3 - 4 } & & $\mathbf{A B , ~ к а у н т и ~}$ & $\mathbf{A B , ~ \% ~}$ \\
\hline \multicolumn{5}{|c|}{ перший місяць лактації } \\
\hline 1 & $81,54 \pm 1,92$ & $76,16 \pm 2,50$ & $5,38 \pm 0,51$ & 6,60 \\
\hline 2 & $88,96 \pm 2,04$ & $76,24 \pm 1,68$ & $12,72 \pm 0,76$ & $14,24^{*}$ \\
\hline 3 & $92,16 \pm 1,86$ & $78,12 \pm 1,72$ & $14,04 \pm 0,82$ & $15,23^{* *}$ \\
\hline Середнє & $87,52 \pm 1,94$ & $76,84 \pm 1,97$ & $10,71 \pm 0,69$ & 12,02 \\
\hline \multicolumn{5}{|c|}{ другий місяць лактації } \\
\hline 1 & $81,32 \pm 1,36$ & $66,32 \pm 1,56$ & $15,00 \pm 0,50$ & 18,45 \\
\hline 2 & $89,66 \pm 1,54$ & $67,36 \pm 1,82$ & $22,34 \pm 1,12$ & 24,92 \\
\hline 3 & $92,14 \pm 1,82$ & $69,34 \pm 2,02$ & $22,80 \pm 0,56$ & 24,74 \\
\hline Середнє & $87,71 \pm 1,56$ & $67,67 \pm 1,74$ & $20,05 \pm 0,73$ & 22,86 \\
\hline
\end{tabular}

Примітка: **p $<0,01-$ у порівнянні з контрольною групою.

Таблиия 6. Вміст основних класів ліпідів у молоці корів, в середньому, за період досліду $(\mathrm{M} \pm \mathrm{m}, \mathbf{n}=\mathbf{5}$, каунти)

\begin{tabular}{|c|c|c|c|c|}
\hline $\begin{array}{c}\text { Групи } \\
\text { тварин }\end{array}$ & Фосфорилхолін & Холестерол & $\begin{array}{c}\text { Сумарна } \\
\text { фракція } \\
\text { фосфоліпідів }\end{array}$ & $\begin{array}{c}\text { Сумарна фракція } \\
\text { триацилгліцеролів }\end{array}$ \\
\hline 1 & $1652,96 \pm 11,02$ & $1054,66 \pm 10,34$ & $318,32 \pm 3,02$ & $175,56 \pm 2,04$ \\
\hline 2 & $1688,42 \pm 8,34$ & $1136,12 \pm 8,58$ & $356,74 \pm 3,08$ & $198,36 \pm 1,88^{*}$ \\
\hline 3 & $1703,84 \pm 9,26$ & $1196,42 \pm 9,32$ & $394,12 \pm 2,96^{*}$ & $218,34 \pm 1,96^{*}$ \\
\hline
\end{tabular}

Примітка: **p $<0,01-$ у порівнянні 3 контрольною групою.

Адсорбційна здатність тканин молочної залози корів відобразилася на молочній продуктивності корів. В середньому, від тварин контрольної групи отримано 1560 кг молока $4 \%$ жирності, а від тварин другої та третьої груп - в 1,10-1,15 раза більше.

В перспективі дослідження з даного напряму дозволять визначити вплив зміни співвідношення кормів у раціоні корів на забезпеченість тканин молочної залози попередниками для синтезу складових компонентів молока, активізувати процеси рубцевої ферментації та підвищити продуктивність тварин.

\section{Висновки}

1. Зміна співвідношення кормів у раціоні сприяло активації синтезу летких жирних кислот у рубці корів дослідних груп, відповідно, в 1,06, в 1,11, в $1,18(\mathrm{p}<0,05)$ та в $1,10(\mathrm{p}<0,05)$, в 1,17 та в 1,23 раза $(\mathrm{p}<0,01)$ порівняно 3 початком досліду, а у тварин контрольної групи даний показник практично не змінювався.

2. Кількість амілолітичних мікроорганізмів у рубці корів першої групи коливалась від $3,86 \pm 0,24$ до $3,94 \pm 0,26$ млн/мл, а у тварин другої групи їх кількість підвищилася до кінця першого місяця досліду в 1,12 раза $(\mathrm{p}<0,05)$, другого - в 1,18 раза $(\mathrm{p}<0,01)$, а третьої - в 1,22 раза $(\mathrm{p}<0,01)$.

3. Кількість целюлозолітичних мікроорганізмів у вмістимому рубця у корів другої групи підвищувався впродовж досліду в 1,13 , в 1,32 в 1,37 раза, а у корів третьої групи - в 1,47 , в 1,74 , в 1,82 раза у порівнянні з даним показником тварин першої групи $(\mathrm{p}<0,01)$.

4. Вміст незамінних амінокислот у вмістимому рубця корів другої та третьої груп виявився на 8,24-12,86\%, більше, ніж у корів першої групи, а загальний амінокислотний пул вмісту рубця - на 10,0-10,8 \%.

5. Використання сумарної фракції триацилгліцеролів по молочній залозі корів першої групи у період першого та другого місяців досліджень коливалося від 6,0 до 18,45 \%, що було в 2,16-1,35 раза та в 2,31-1,24 раза менше, ніж у тварин другої та третьої груп $(\mathrm{p}<0,01)$.

6. Адсорбційна здатність тканин молочної 
залози відобразилася на молочній продуктивності корів, яка у тварин контрольної групи становила 1560 кг молока 4 \% жирності, що в 1,10-1,15 раза менше, ніж продуктивність корів дослідних груп.

\section{References}

Bauman, D. E. \& Griinari, J. M. (2002). Regulation and nutritional manipulation of milk fat: low-fat milk syndrome. In Mol, J. A. \& Clegg, R. A. (Eds.). Biology of the Mammary Gland (Advances in Experimental Medicine and Biology). Boston : Springer. doi: https://doi.org/10.1007/0-306.

Bauman, D. E., Perfield, J. W., Harvatine, K. J. \& Baumgard, L. H. (2008). Regulation of fat synthesis by conjugated linoleic acid: lactation and the ruminant model. J. Nutr. 138, 403-409. doi: https://doi.org/10.1093/jn/138.

Chumachenko, V.Yu., Stoianovskyi, S. V. \& Lahodiuk, P. Z. (1989). Dovidnyk po zastosuvanniu biolohichno aktyvnykh rechovyn u tvarynnytstvi [Handbook on the use of biologically active substances in animal husbandry]. Kyiv : Urozhai [in Ukrainian].

Chung, Y. H., Zhou, M., Holtshausen, L., Alexander, T. W., McAllister, T. A., Guan, L. L. ... Beauchemin, K. A. (2012). A fibrolytic enzyme additive for lactating Holstein cow diets: ruminal fermentation, rumen microbial populations, and enteric methane emissions. J Dairy Sci., 95 (3), 1419 1427. doi: 10.3168/jds.2011-4552.

Kambur, M. D., Zamazij, A. A. \& Tretiakova, T. R. (2018). Vplyv umov utrymannia koriv na sekretoutvoriuiuchu funktsiiu tkanyn molochnoi zalozy [The influence of housing conditions on cows on the secretory function of breast tissue] Materialy naukovo-praktychnoi konferentsii vykladachiv, aspirantiv ta studentiv Sumskoho NAU (Yol. 2) (p. 76). Sumy [in Ukrainian].

Kambur, M. D., Zamazij, A. A., Kolechko, A. V. \& Ostapenko, S. V. (2018). Vplyv proteyinovogo zabezpechennya tvaryn na rubcevu fermentaciyu ta produktyvnist [Influence of animal protein supply on scar fermentation and productivity]. Veterynariia, tekhnolohii tvarynnytstva ta pryrodokorystuvannia, 1, 107-109 [in Ukrainian].

Khairullyn, A., Letiahyn, A. \& Molodkyn, V. (2020). Polnotsennoye kormleniye molochnogo skota osnova realizatsii geneticheskogo potentsiala produktivnosti [Full-fledged feeding of dairy cattle is the basis for the realization of the genetic potential of productivity]. Ahrovestnyk, 5, 20-47 [in Russian].
Medinger, R., Nolte ,V., Pandey, R. V., Jost S., Ottenwaelder, B., Schloetterer, C. \& Boenigk, J. (2010). Diversity in a hidden world: potential and limitation of the protozoa in the rumen nextgeneration sequencing for surveys of molecular diversity of eukaryotic microorganisms. Mol Ecol., 19, 32-40. doi: 10.1111/j.1365-294X.2009.04478.x.

Newbold, C. J., de la Fuente, G., Belanche, A., Ramos-Morales, E. \& McEwan, N. R. (2015). The role of ciliate protozoa in the rumen. Front Microbiol. 6, 1313. doi: 10.3389/fmicb.2015.01313.

Pappritz, J., Meyer, U., Kramer, R., Weber, E-M., Jahreis, G., Rehage, J. ... Dänicke, S. (2011). Effects of long-term supplementation of dairy cow diets with rumen-protected conjugated linoleic acids (CLA) on performance, metabolic parameters and fatty acid profile in milk fat. Arch. Anim. Nutr., 65, 89-107. doi: https://doi.org/10.1080/174503.

Russel, J. B. \& Rychlik, J. L. (2001). Factors that alter rumen microbial ecology. Science, 11, 11191122. doi: 10.1126/science,pmid:1058830.

Sachuk, R. M., Katsaraba, O. A., Dmytriv, O. Ya. \& Stravskyi, Ya. S. (2018). Diahnostyka metabolichnykh zrushen v orhanizmi koriv u period sukhostoiu ta rozrobka preventyvnykh zakhodiv [Diagnosis of metabolic changes in the body of cows during the dry period and the development of preventive measures]. Naukovi horyzonty, 9-10 (71), 69-74 [in Ukrainian].

Schlegel, G., Ringseis, R., Windisch, W., Schwarz, F. J. \& Eder, K. (2012). Effects of a rumenprotected mixture of conjugated linoleic acids on hepatic expression of genes involved in lipid metabolism in dairy cows. J. Dairy Sci. 95, 39053918. doi: https://doi.org/10.3168/jds.20.

Tyurenkova, E. N. \& Vasilyeva, O. P. (2013). Kormleniye kak osnovnoy faktor produktivnogo dolgoletiya molochnoy korovy [Feeding is a key factor for lang productive life of a daire cow]. Farm Animals. 4, 42-54 [in Russian].

Vlizlo, V. V., Fedoruk, R. S. \& Makar, I. A. (2004). Fizioloho - biokhimichni metody doslidzhen u biolohii, tvarynnytstvi ta veterynarnii medytsyni [Physiological - biochemical research methods in biology, animal husbandry and veterinary medicine]. Lviv [in Ukrainian].

Yablonskyi, V. A. (2014). Problema vidtvorennia tvaryn $\mathrm{u}$ novykh umovakh [The problem of reproduction of animals in new conditions]. Veterynarna medytsyna Ukrainy, 5, 24-27 [in Ukrainian]. 